\title{
Space Transmission: Overseas Forces for Sports Industry Development in Fujian and Guangdong Province, the Hometown of Overseas Chinese*
}

\author{
Huijie Guo \\ School of Physical Education and Sport Science \\ Fujian Normal University \\ Fuzhou, China 350007
}

\begin{abstract}
By means of literature, interview and logical analysis, this paper analyses the spatial transmission and internal mechanism of the interaction between overseas Chinese and overseas Chinese sports industry in the early period of the reform and opening up. Space transmission is mainly embodied in: overseas Chinese participate in the development process of sports industry in overseas Chinese hometown through the investment of funds, the establishment of overseas Chinese enterprises ;through transnational networks, they introduce advanced human resources, information technology, management experience and other resource elements; through the overseas Chinese merchants Network, the sports industry of overseas Chinese hometown will be linked to the global economic division of labor and cooperation system. The driving force of space transmission is mainly due to the guidance of the national policy on overseas Chinese affairs at the macro level, the mutual benefit mechanism for the local governments at the meso-level and the echo of the non-governmental networks of the overseas Chinese hometown at the micro level. It is this stereoscopic and multidimensional dynamical mechanism that has strongly promoted the coupling of the formal and informal systems in the development of the sports industry in the overseas Chinese hometown of Fujian and Guangdong, the top-down and bottomup interactions, and the cross-border connection between overseas Chinese hometown society and overseas resources.
\end{abstract}

Keywords-space transmission; the hometown of overseas Chinese in Fujian and Guangdong; sports industry; overseas force

\section{INTRODUCTION}

Fujian and Guangdong are well-known hometowns of overseas Chinese and have a large number of overseas Chinese resources. They are also the frontline for reform and opening up. It is precisely this special location, culture, and customs that have developed a special route for the development of sports industries in overseas Chinese hometown, forming a unique development model. Historically, many overseas Chinese in Fujian and Guangdong have been traveling back and forth between Southeast Asia, Europe and the United States and other countries and regions for a long

*Fund project: supported by the national social science fund project, the overseas Chinese in the Republic of China have had a great influence on the sports development in the overseas Chinese hometown of South Fujian. time, weaving a huge social network connecting domestic and foreign overseas Chinese hometown. In the era of global economic integration, the phenomenon of transnational migration has become more frequent. Chinese businessmen's transnational economic practices "have often promoted major changes of economy and society of local and even the country of their homelands" ${ }^{1}$. More studies have shown that the transnational migration of immigrants often promotes the transfer of human resources from the immigration country to the transit country, and then returns to the emigrating country. In this process, an effective human capital can be realized. ${ }^{2}$ Not only that, various elements such as finance, science and technology, information, management experience, and values have gradually formed cross-border Chinese business networks that are closely related and deeply integrated, as overseas Chinese frequently cross national borders. From the perspective of transnational theory, transnational social space is a complex link spanning multiple realms, networks and organizations $^{3}$. In fact, transnational social space is not limited to the structure of static social relations, but is also a representation of cultural convergence. Various heterogeneous cultures converge gradually in the continuous expansion and extension of the world economic system. This spatial transfer through cross-border flows has brought about both explicit manpower and economic capital for the development of the sports industry in the overseas Chinese hometown of Fujian and Guangdong as well as an inclusive culture of "different" and the recessive power of thought. During the course of the development of the sporting goods industry in the overseas Chinese townships in Fujian and Guangdong Provinces, especially during the initial period of reform and opening up, the space transmission generated from external assets, operations, management, technology, markets, business

Longqi Chao. The Transnational Theory in the Study of Migration History [J].Historiography Quarterly, 2007 (3) : 52-63

Devoretz, Z Ma. Triangular human capital flows between sending, entrepot and the rest of the world regions[J].Journal of the American Chemical Society, 2002, 2004(17):99-105

G Rieger. The Volume and Dynamics of International Migration and Transnational Social Spaces[M].OX-ford, UK: Oxford university press, 2000:191. 
awareness, etc. transferred by relatively advanced countries or regions at that time with the linkage of overseas Chinese has led to the rapid development of the overseas Chinese hometown sports industry, especially the manufacturing of sporting goods at an extraordinary speed, and has produced a huge industrial effect. Therefore, in the period when the sports industry has entered a period of globalization and internationalization, under the background of the national Belt and Road Strategy, it is clear that the backtracking and exploration for spatial transmission effects and internal mechanisms of the sports industry in Fujian and Guangdong in the early days of reform and opening up were obviously have pretty theoretical significance and practical value.

\section{SPACE TRANSMISSION}

\section{A. Industrial Transmission}

In the initial period of reform and opening up, due to the natural geographical and kinship advantages of overseas Chinese homeland, Guangdong and Fujian have naturally become the regions in the mainland that initially undertake the transfer of the international sporting goods industry. The development of the sports industry in Fujian and Guangdong, especially the sporting goods industry, is inextricably linked with the injection of overseas Chinese capital (mainly for the Southeast Asia consortium and Hong Kong and Taiwan funds).With the rise of the world wave of sporting goods industry transfer, overseas Chinese capital in Southeast Asia began to transfer to Fujian and Guangdong overseas Chinese townships, mainly focusing on labor-intensive sports equipment and manufacturing. First, the sports footwear industry. For instance, Quanzhou Ryukyu, Putian Overseas Chinese, Guo's Footwear, Fengdeng Shoes, Dongguan Yongrong, Dongguan Yuyuan, Haojian International, and Nanliang Group have mushroomed. Second, the sports equipment industry. For example, Xiamen Qiaoxing, Weishi Sports, Guangdong Zhongying Baseball and Softball Manufacturing Factory, and Ridongsheng Sporting Goods Co., Ltd. have continuously emerged. In the initial stage of the development of the sports industry in Fujian and Guangdong, some local villagers have been able to set up home-workshopstyle enterprises through the funds, equipment, and technical assistance of overseas Chinese. Since then, with the gradual improvement of technology and management level, through overseas information channels of overseas Chinese and the undertake of some orders from Nike, Adidas and other international brands, the sporting goods industry of overseas Chinese hometown further involved in the international division of labor, and started the OEM production mode. With the gradual deepening of reform and opening up, the main distribution areas of overseas Chinese in the southern Fujian Delta and Guangdong Pearl River Delta have gradually developed into economically developed regions in coastal areas. The rapid economic and social development has naturally brought about a change in the concept of life. The new social demand has become the internal thrust of production and social development, and it also provides new opportunities for the development of sports industry and structural optimization. The continuous influx of a large number of foreign and overseas Chinese businessmen has spawned a new demand for the sports industry, which has contributed to the development of the leisure sports industry in overseas Chinese hometown. New leisure sports such as golf and surfing have emerged in overseas Chinese hometown. For example, Hong Kong China-Australia Investment Co., Ltd., Hong Kong Shi Huang Company and other enterprises have jointly built the Hot Spring Golf Course in Zhongshan Guangdong, which is China's first international standard golf course; Hong Kong United Group, Japan's Mitsui Real Estate Sales Co., Ltd., and Taiwanese Funds jointly invested in the construction of the Fuzhou Dengyun Golf Country Club, forming a sports and leisure base that focuses on golf operations and integrates culture, sports, and entertainment. The Xiamen Kaige Golf Club created by a joint investment from Hong Kong and Taiwan overseas Chinese businessmen "promotes the development of Xiamen's economy and tourism, and provides convenience for foreign businessmen and overseas Chinese merchants in Xiamen" ${ }^{4}$. Gold Coast Racing Club (Hong Kong Capital) is located in Shishi Yongning Gold Coast Resort with an area of 150 acres. It enjoys a race track with international standards and has a rainproof stand that can accommodate 30,000 spectators. President of Matsuya Building Co., Ltd., Osaka, Japan, who has extensive experience in surfing project management, has invested and operated in Fujian Surf Swimming Pool Co., Ltd. ${ }^{5}$

\section{B. Technical Transmission}

The equipment donation of overseas Chinese and the introduction of technology have created an upsurge of the factory establishment among overseas Chinese. What was particularly important was that machines and equipment donated by overseas Chinese and overseas Chinese belong to the leading domestic and international level at that time, which directly enhanced the company's technical strength and professional production capabilities, promoting the improvement of product quality and market competitiveness.

Among them, overseas Chinese businessman, Chen Yongpei, returned home to invest, setting up a typical example. As early as 1988, Chen Yongpei returned to his hometown, Quanzhou, as an overseas Chinese in the Philippines to set up a factory and started the history of the "Ryukyu" venture. Due to the rich overseas resources and the country's vision, Ryukyu Shoe \& Garment Co., Ltd. has been able to develop rapidly. The R\&D centers, SATRA laboratories, Quanfeng Shoes Factory, Hongzhan Mould Factory, and Athletic Shoes Factory have been established one after another to form a complete industrial chain. Overseas Chinese businessmen have brought advanced management experience and cuttingedge technologies in the process of investing in the Fujian and Guangdong sports industry, which has promoted the establishment of regional innovation systems in the hometown

Fei Ma. He Built the First-Class Golf Course in Xiamen - Interview with Mr. Chen Kai, Chairman of Kaige (Xiamen) Golf Course[N].Overseas Chinese in Fujian, 1990-04-15.

5 Shangyuan Xu. Fujian Will Build a Surfing Pool - the First SinoForeign Joint Venture Project in the Province Sports Industry to Sign A Contract [N].Overseas Chinese in Fujian, 1987-8-23. 
of overseas Chinese, and driven the industry towards highlevel, high-tech transformation and development. For example, Beibei Town, Pingzhou Town, and Zhangcha Town in Guangdong, which are clustered by overseas Chinese-funded sporting goods companies, have developed into the "State Spark-intensive areas."It can be seen that the new technologies introduced by a large number of overseas Chinese enterprises at that time had a profound impact on the technological transformation and industrial upgrading of the overseas Chinese sports industry.

\section{Market Transmission}

Since the reform and opening up, the sports industry in Fujian and Guangdong overseas Chinese hometown has formed a special development path. There are a large number of overseas Chinese-funded enterprises and joint ventures in Houjie Town, Dongguan City, Guangdong Province, Pengtian Village, Lingxiu Town, Shishi City, and Chendai Town, Jinjiang City. In the middle and late 1980s, Hong Kong capital, American capital, and mixed investment companies continued to emerge in places such as Dongguan, Nanhai, and Fanyu in Guangdong, and output and export volume of footwear enterprises in Guangdong township had the highest in the country. Among them, the majority of sports shoes were produced by foreign (overseas) joint capital and cooperative ventures. Overseas Chinese-funded enterprises mainly dealt with agents with main products of sports shoes, ball games, sports equipment, and they were distributed in the Pearl River Delta region ${ }^{6}$. The involvement of a large number of overseas Chinese enterprises has laid an important foundation for the Fujian-Guangdong sports industry to form a professional market and generate amass effect.

At the same time, the Fujian-Guangdong Chinese merchant network has also played a role as a bridge and link in the process that China's local industrial clusters enter the global production network, and it has become the most important driving force in the process of industrialization and urbanization of the southeast coast ${ }^{7}$. Overseas Chinese of Fujian and Guangdong established sports companies around the world as early as the 1970s. The Chinese merchant network plays a role of matchmaking, internal leads and outreach in the sports industry, which is not only helpful for introducing capital, advanced technology, and outstanding overseas talents, but also turning to outside from inside timely and establishing networks of commodity sales for Chinese companies around the world, especially in the Asia-Pacific region by the World Chinese Business Network. And it will be more convenient to invest in factories abroad and expand the overseas markets of Chinese companies. Overseas businessmen network from all over the world serve to introduce funds and others and communicate with foreign parties, which, on the one hand, revitalize both international

$6 \quad$ Edited By the Local Chronicle Compilation Committee of Guangdong province. Guangdong Provincial Chronicles · Township Enterprises Chronicles[Z].2006,112-113.

7 Jici Wang, Ting Tong.On the Local Industrial Clusters under the Background of Globalization -- the Source of Local Competitive Advantage [J].Strategy and Management,2001,(6):35. and domestic resources, on the one hand, makes it easy to develop both domestic and international markets. Today, Anta, Xtep and other overseas Chinese sports brands have opened stores in some countries in Southeast Asia. Peak has also established a branch in the Philippines and has established branches in Australia and New Zealand near Southeast Asia. 
TABLE I.

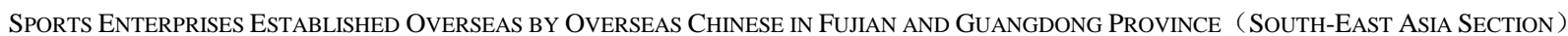

\begin{tabular}{|c|c|c|c|}
\hline Company Name & Nature & Business Operations & Note \\
\hline Wanneng Co., Ltd. & Malaysian Chinese-funded enterprise & Sports Gaming & Cantonese overseas Chinese businessmen \\
\hline YTL & MalaysianChinese-funded enterprise & Horse racing, golf, etc & Cantonese overseas Chinese businessmen \\
\hline Modern Golf Club & Indonesian Chinese-funded enterprises & Golf-related industries first & Cantonese overseas Chinese businessmen \\
\hline SM Sports Co., Ltd. & Thailand Chinese-funded enterprises & Country Golf Club & Cantonese overseas Chinese businessmen \\
\hline Xielian Group & Thailand Chinese-funded enterprises & $\begin{array}{l}\text { Various modern sports equipment } \\
\text { first }\end{array}$ & Cantonese overseas Chinese businessmen \\
\hline Aneka Industrial Co., Ltd. & Indonesia Chinese-funded enterprises & Nike authorized manufacturer & Cantonese overseas Chinese businessmen \\
\hline Qingshan Group & Thailand Chinese-funded enterprises & $\begin{array}{l}\text { Operating and producing } \\
\text { international ski equipment }\end{array}$ & Cantonese overseas Chinese businessmen \\
\hline $\begin{array}{l}\text { Mongaran Industry Co., } \\
\text { Ltd. }\end{array}$ & MalaysianChinese-funded enterprise & $\begin{array}{l}\text { Listed enterprises, producing } \\
\text { sports shoes }\end{array}$ & Fujian overseas Chinese businessmen \\
\hline CHHB & MalaysianChinese-funded enterprise & $\begin{array}{l}\text { Main golf, fitness and other } \\
\text { industries }\end{array}$ & Fujian overseas Chinese businessmen \\
\hline Genting Group & MalaysianChinese-funded enterprise & $\begin{array}{l}\text { Management of sports tourism } \\
\text { and other leisure industries }\end{array}$ & Fujian overseas Chinese businessmen \\
\hline $\begin{array}{l}\text { Indo shoe industry Co., } \\
\text { Ltd. }\end{array}$ & Indonesia Chinese-funded enterprises & $\begin{array}{l}\text { Production of Reebok and Adidas } \\
\text { sports shoes }\end{array}$ & Fujian overseas Chinese businessmen \\
\hline
\end{tabular}

a. The main source of information: Guangdong Overseas Chinese News; Fujian Overseas Chinese News; Encyclopedia of Overseas Chinese mainly edited by Zhou Nanjing (the volume of economy)

\section{System Transmission}

Since China's reform and opening up, the main method of institutional innovation has been supply-led innovation or change. However, in the hometown of overseas Chinese, because of the small scale of the organization, according to Olson's theory, it is easy to achieve collective action; in addition, because it is far from the center of power, it is easy to tap the space of activity on the margin of the system to carry out institutional innovation ${ }^{8}$. With the socio-economic transition of overseas Chinese hometowns, the local public services required for the rapid development of the sports industry rely solely on the government's official promotion is far from enough. Overseas Chinese have promoted the process of local government public service construction in the interaction with sports industry development of overseas Chinese hometown in the bottom-up way from information services, development planning and other aspects. It is in the ongoing interaction with overseas Chinese that the FujianGuangdong overseas Chinese hometown developed the "threeto-one" business earlier, promoting individual, private, partnership, Sino-foreign joint ventures and other non-public ownership economies and a variety of joint-stock cooperative system. Meanwhile, the ownership structure of sports industry in overseas Chinese hometowns has also been improved. In turn, all these actions forced the public service reform of local government, and took this as a breakthrough point to actively participate in the international division of labor, gradually forming an international sports equipment manufacturing base."Jinjiang model", "Dongguan model", "Xiqiao model" have been continuing to emerge, which all of them contain the power of overseas Chinese. The development mode of the sports industry in the overseas Chinese hometown of Fujian and Guangdong is constantly being constructed and matured in the interactive symbiosis between overseas Chinese and overseas Chinese hometown. The three, the hometown of overseas Chinese - overseas Chinese (Overseas Chinese) - the world, constitute an interactive "cross-border field". The overseas Chinese in Fujian and Guangdong connect the hometown of overseas Chinese with the world, and involve the development of sports industry of overseas Chinese hometown in the international division of labor system, forming a special model for the sports industry development of overseas Chinese hometown.

\section{E. Conceptual Transmission}

The enterprise culture of overseas Chinese hometown is the regional spirit mark and spiritual power of the development of sports industry in Fujian and Guangdong. Overseas Chinese not only play a role in "hardware" conditions such as capital and equipment, but also drive the development of overseas sports industry, especially the sporting goods industry development model from the space transmission, such as development concept, management experience, brand awareness and other aspects. The overseas Chinese in Fujian and Guangdong have long been accustomed to traveling from the east and the west, so that they have a variety of institutional experiences and multiple cultural backgrounds. They are both familiar with China's national conditions and the realities of overseas Chinese, and meanwhile, they have a deep understanding of world trends and development experiences. Therefore, overseas Chinese's contribution to the economic development of overseas Chinese homeland is not merely the introduction of foreign capital, but also the use of the game rules of the market

8 Minghuan Li. Investigation of the Hometown of Overseas Chinese in Fujian: the Identity, the network and the Culture of the Hometown of Overseas Chinese[M].Xiamen: Xiamen University Press, 2005:267. 
economy for the overseas Chinese hometown. ${ }^{9}$ At that time, we lacked funds and technology and lacked awareness of the market. Overseas villagers suggested using relatively cheap land resources and lower labor costs to undertake some industries and capital outside" 10 . It can be seen that overseas Chinese's contribution to the sports industry in Fujian and Guangdong overseas Chinese townships, in addition to financial support, technology introduction, and overseas market development, what more important is that they once again activate the inherent adventurous spirit and the local commercial cultural tradition that favors merchants for profit of the people in overseas Chinese hometown through what they have experienced overseas. At the same time, overseas Chinese capital enterprises have also produced significant demonstration effects in terms of branding and marketing network construction, technological innovation, and entrepreneurial spirit formation in overseas Chinese hometown sports goods enterprises.

\section{CONCLUSION}

Huntington put it out: "If the population distribution is determined by nature, then population mobility is the engine

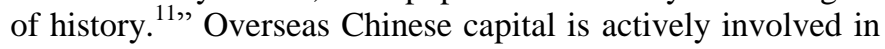
the development of the sports industry in overseas Chinese hometowns, which includes the sense of identity in hometown culture and motivations for gaining capital appreciation by means of investment. After being equipped by the modern business sense of the European world, overseas Chinese living in overseas Chinese hometown have formed a "comparative advantage" in management, information, and experience. The cross-national multi-interaction network formed by "overseashometown contact" has played a "bottom-up" promoting role in the development and booming of the sports industry in Fujian and Guangdong overseas Chinese hometown. In general, in the budding, forming, and developing history of the overseas Chinese hometown sports industry in Fujian and Guangdong, overseas Chinese have played an integral role of space transmission in capital support, technology introduction, management experience, market development, and business philosophy. It is precisely by this special role that the overseas Chinese go deep into the ideological level from the artifacts, systems, and ideological level, thereby effectively integrating the development of the Fujian and Guangdong sports industry into the process of modernization, internationalization, and globalization of the sports industry. At present, under the background of the scientific and technological revolution, globalization, and internationalization, the level of cooperation between overseas Chinese in the sports industry of overseas Chinese hometown is constantly improving, and

\section{Speech by Huang Mengfu, vice president of the National} Federation of Industry and Commerce, at the 2013 World Chinese businessman Conference[R].2003-07-28.

10 The author's interview with Mr. Zhang Mouchang, the former officer of United Front Department of Jinjiang Municipal Committee.

11 [US] Huntington (translated by Cheng Kexiong). Who are we? The Challenges to the National Characteristics of the United States [M]. Beijing: Xinhua Publishing House, 2005:16. the cooperation in the high-tech field will gradually become the focus.

Of course, the leading effect of the sports industry development model in the overseas Chinese hometown of Fujian and Guangdong is highlighted by the fact that the connection between China and the outside world is not extensive and the breadth and depth of reform and opening up have not yet reached a certain level. This is a product of a specific era and has certain limitations. For the discussion of the development of sports industry and overseas Chinese, it is neither possible to ignore the historical performance in a specific period nor to amplify the special significance of space transmission.

\section{REFERENCES}

[1] Longqi Chao. The Transnational Theory in the Study of Migration History [J].Historiography Quarterly，2007（3）：52-63. 潮龙起.移 民史研究中的跨国理论[J].史学理论研究, 2007（3）：52-63.

[2] Devoretz, Z Ma. Triangular human capital flows between sending, entrepot and the rest of the world regions[J].Journal of the American Chemical Society, 2002, 2004(17):99-105

[3] G Rieger.The Volume and Dynamics of International Migration and Transnational Social Spaces[M].OX-ford,UK:Oxford university press,2000:191.

[4] Fei Ma. He Built the First-Class Golf Course in Xiamen - Interview with Mr. Chen Kai, Chairman of Kaige (Xiamen) Golf Course[N].Overseas Chinese in Fujian, 1990-04-15. 马非.他在厦门 建第一流高尔夫球场-访凯歌（厦门）高尔夫球场董事长陈恺先生 [N].福建侨报, 1990-04-15.

[5] Shangyuan Xu. Fujian Will Build a Surfing Pool - the First SinoForeign Joint Venture Project in the Province Sports Industry to Sign A Contract [N].Overseas Chinese in Fujian, 1987-8-23. 许上元. 福建将 建冲浪游泳池一一省体育界第一个中外合资项目签订合同 $[\mathrm{N}]$. 福建 侨报,1987-8-23.

[6] Edited By the Local Chronicle Compilation Committee of Guangdong province.Guangdong Provincial Chronicles-Township Enterprises Chronicles[Z].2006,112-113. 广东省地方志编纂委员会编.广东省 志·乡镇企业志[Z].2006,112-113.

[7] Jici Wang, Ting Tong. On the Local Industrial Clusters under the Background of Globalization -- the Source of Local Competitive Advantage [J].Strategy and Management,2001,(6):35. 王缉慈,童听. 论 全球化背景下的地方产业群一一地方竞争优势的源泉 $[\mathrm{J}]$. 战略与管 理,2001,(6):35.

[8] Minghuan Li.Investigation of the Hometown of Overseas Chinese in Fujian:the Identity, the network and the Culture of the Hometown of Overseas Chinese[M].Xiamen:Xiamen University Press, 2005:267. 李 明欢.福建侨乡调查: 侨乡认同、侨乡网络与侨乡文化 $[\mathrm{M}]$. 厦门:厦 门大学出版社, 2005:267.

[9] Speech by Huang Mengfu, vice president of the National Federation of Industry and Commerce, at the 2013 World Chinese businessman Conference[R].2003-07-28. 全国工商联副主席黄孟复在 2013 年世界 华商大会的讲话[R].2003-07-28.

[10] The author's interview with Mr. Zhang Mouchang, the former officer of United Front Department of Jinjiang Municipal Committee. 笔者对原 晋江市委统战部张谋场先生的访谈.

[11] Kathleen Thelen and Sven Steinmo, Historical Institutionalism in Comparative Politics, in Sven Steinmo , Kathleen Thelen, and Frank Longstreth, eds., Structuring Politics: Historical Institutionalism in Comparative Analysis, Cambridge: Cambridge University Press,2007. 